\title{
Gender and Business Competencies of Knowledge Workers in Poland
}

\author{
Jolanta Kowal \\ University of Wrocław, Institute of Psychology, Poland \\ jolanta.kowal@uwr.edu.pl
}

\begin{abstract}
The purpose of the research described in this article is to verify the influence of gender difference and firm size on the business competencies self-assessment of knowledge workers in small regional enterprises of Lower Silesia region, in Poland, a transition economy. An individual survey was conducted on the basis of the questionnaire of business competencies. Two trials of 169 knowledge workers were constructed via an interpersonal network and sequential random sampling, with the use of passive experimental design. Several dimensions of business competencies are investigated. The results show that females working as knowledge workers in regional small enterprises in Poland manifest less levels of business competencies self-assessment than male colleagues. However, females have the highest scores in sphere of knowledge self-assessment concerning organizational units and organizational responsibility. The novelty is the first use the adapted questionnaire of business competencies self-assessment among knowledge workers in relation to gender and regional small and micro firms, in Poland.
\end{abstract}

\section{Introduction}

Effective and successful management of organizations is characterized by factors that lead to economic growth via innovations as new business competencies of knowledge workers. Skilled, highly qualified and innovative employees contribute to organizational performance and make organizations more successful in reaching their goals [17, 23, 31, 43].

In the modern global digital economy, knowledge workers and Information Technology (IT) professionals play an important role in creating business values for organizations [13, 14, 37]. However, not many research studies systematically investigate the business competencies self-assessment of knowledge workers as basis for innovations [20, 25, 27, 38]. Rather little is known about the effects of gender and firms size differences in business competencies self-assessment of knowledge workers working in small regional enterprises, with special treatment of micro-firms, in transition economies [20, $25,43]$. Transition economies are countries in the long process of transforming from centrally planned economies to market economies $[42,43]$. They become knowledge economics. The knowledge economy may be defined as production and services based on knowledge-intensive activities contributing to an accelerated pace of technical and scientific advance, and rapid obsolescence [6, 8, 37]. Knowledge economic is characterized by the financial impact on knowledge creation, modification, distribution and use of intellectual capital [6, 7, 8]. Besides that, characteristic for knowledge economies is their stronger reliance on intellectual capabilities than on physical inputs or natural resources $[37,11]$. Thus, the role of learning and continuous innovation inside firms constantly increases $[11,12]$.

The power of the modern knowledge-based economy is based on information systems (IS) and human resources i.e. productive knowledge workers being typically IT professionals [24, 31]. Professional services and other information-rich industries, noted the marked growth in employment in these sectors of the economy since the thirties $[11,35]$. The strongly internetworked business systems represent a new source of value for customers and wealth for shareholders. The core competencies of each participant become the key factor of success in this business approach $[3,20,28,51]$. Therefore, very important role play knowledge workers. The term "knowledge worker" refers to employees who have a high level of education, experience and organizational status and, therefore, allows them to retain considerable autonomy and discretion in carrying out its work [11, 24]. The main capital of knowledge workers is the knowledge. Such workers are for instance IT professionals, software developers, medical doctors, architects, engineers, scientists, public accountants, lawyers, and academics - shortly those whose job is to "think for a living" [3, 23, 24, 31]. It is possible that the ongoing transformation process has a 
substantial impact on business competencies selfassessment of females working in IT in transition economies. There is lack of studies on this issue in academic journals and dealing with ICT in countries that have abruptly abolished a centrally planned economy and one-party controlled political system in favor of a market-driven economy [5, 42, 43, 46].

The business environment of small regional enterprises is nowadays the field of research and practical applications [20, 24, 25]. According to Henderson and Weiler [16] - small and medium enterprises (SMEs) can be characterized as a major engine of economic growth. There is a positive relationship between the share of SMEs in manufacturing and gross domestic product (GDP) per capita growth $[20,24,25]$. The fundamental prerequisite for successful development of all businesses is a favorable business environment $[5,16$, 31 ] in which the enterprise is able to use its innovative capacity including staffs competences. The knowledgebased organization development in transition economies requires information systems (IS) and human resources with productive knowledge workers consisting of IT users and IT professionals [12, 28, 30, 31]. However, business competencies within transition economies are often lower than in other economies [26, 29, 31]. The higher level of business competence can be achieved at individual level by its self-assessment in relation to requirements of social and business environment. Self-consciousness of a little lower level of own business competence can wake up the need for further education and increase of professional skills.

For a country or a region, the key factor for making a complete transition from a transition to developed status is strong and continuous economic growth [42, 43]. Human development and high standards of living in many countries have been equated with education of the population, computer usage, business competencies leading to the ability to innovate [30, 31, 32]. It is essential to determine these business competencies as improving innovation in regional micro and small enterprises in a transition economy, such as Poland. The author assumes that knowledge workers in small and micro enterprises with higher levels of business competencies can support innovation processes. However, the business competencies may be differentiated by gender and firm size of knowledge workers. In this research, knowledge workers were surveyed to examine how they evaluate their own level of business competencies that support innovation in regional, small knowledge-based organizations in transition economies in Poland. Thus, in this work the author attempts to close this gap and test gender and firm size differences in the business competencies of knowledge workers working in small regional enterprises in Lower Silesia district, in Poland, a transition economy. The main research question guiding current study may be formulated in the following way: is there a difference in perceived business competencies self-assessment of female and male knowledge workers in Poland?

The rest of the article has following structure: after a brief literature review, the author presents two main hypotheses; these hypotheses are tested by data collected by an online survey conducted among 169 knowledge workers employed in small regional enterprises in Lower Silesia district in Poland. After discussing the results of current research, the author points to conclusions.

\section{Background and Hypotheses}

Only little research on business competencies of knowledge workers has been done until now [30, 31, $20,25]$. Although an "obvious gendering in the workforce" is reported [1, 9, 19, 55], most studies report differences in business competencies between female and male knowledge workers as insignificant [10, 19, 41, 48]. In addition, most of the published studies are related to business competencies of employees in developed, mature economies [39, 40]. In contrast, studies about business competencies in transition economies at individual level are rare [20, $26,31]$. Few existing studies on business competencies in transition economies concluded that there are no substantial differences among female and male workers in east-north European countries [1, 2, 22, 34].

It is quite possible, based on fragile human capital framework [20, 25, 26, 27] that studies about business competencies in transition economies in small regional companies might produce different results than previous similar studies conducted in the context of developed economies [20, 23, 26, 31].

Past studies concluded that multiple factors determine the business competencies of IT professionals. However, the results of studies that examined the effects of gender on business competences, assessment of knowledge workers are inconclusive. In contrast, Crump et al. [10] concluded that there is "an obvious gendering in the workforce."

Earlier studies related to business competence in Poland [31] indicated the high importance of two main dimensions: Business Competence (BC) regarding Organization Specific Knowledge, Business Competence regarding Interpersonal and Management Knowledge (Table 2). In current study additional subscale of Business Competence Regarding Intention for Partnership Development (INT) was developed (Tables 2). 
It is quite possible that in transition economies such as Poland, business competencies self-assessment as an element of innovative capability will be affected by unique social, business, and cultural environments, as gender and firm size, especially outside the big cities, in regions [20, 25, 31].

To examine this issue in Poland, the author stated the following hypotheses:

Hypothesis 1: The knowledge workers gender affects their business competencies self-assessment.

Hypothesis 2: The size of the firm in which knowledge workers are employed affects their business competencies self-assessment.

Current research model is depicted in Figure 1.

The author built the conceptual model on the basis of the theory of confirmatory factor analysis (CFA)

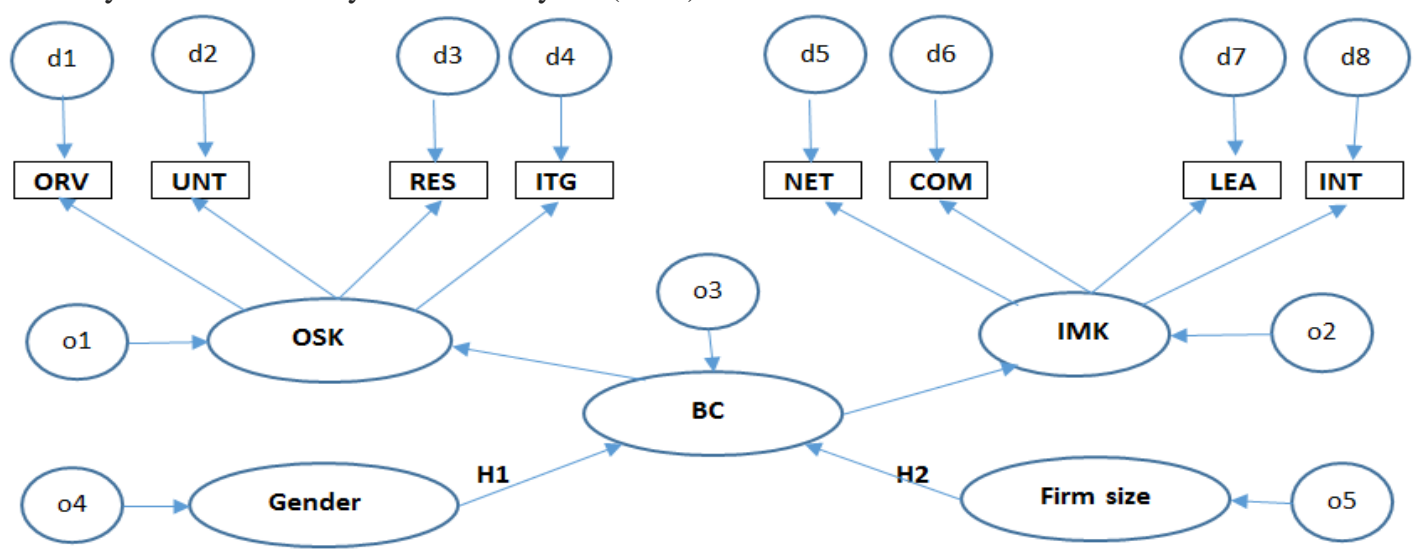

Figure 1. Research Framework

\section{Methodology}

To measure the dependent variables related to business competencies - the earlier version of the Business Competence (BC) Questionnaire was developed [28]. The survey items, including variable codes, are depicted in Table 2. All items were measured on a 5-point Likert-type scale: very low (1), low (2), neutral (3), high (4), very high (5). The independent variables: gender and firm size were binary coded. For the purpose of multivariate analysis as multiple regression, analysis of variance or factor analysis, the data were transformed into frequencies and standardized [20, 24, 26]. Statistical methods comprised descriptive statistics, point estimation, confidence intervals, hypotheses verification and multivariate analyses. For current study, significant results were presented. Analyzes were performed by the author using statistical software STATISTICA 12.

\subsection{Procedural Stages and Questionnaire}

and Structural Equation Modelling [18, 44, 47] and own previous analytic studies [20, 25, 29]. Assumed model includes two parts: 1) the measurement model which relates measured observable variables (Table 2) in rectangles: for example [OVR, ..., INT] to hidden, directly unobservable, latent variables (in ellipses: BC, OSK, IMK, Gender, Firm size); 2) the structural model that relates latent variables to one another $($ Gender $\rightarrow(B C)$, Firm size $\rightarrow(B C), B C \rightarrow(O S K$, IMK $)$ ). Variables $\mathrm{d} 1, \mathrm{~d} 2, \mathrm{o} 1, \ldots \mathrm{o} 3$ are residuals - that represent an influence of other, unknown variables that were not considered in current model. 
E. Initial standardization of the test to the respective population;

F. Verification of the structural relations between the dimensions of the test;

G. Preparing of methodical indications for application of the test $[35,31,25,26]$.

Table 2. Items for Business Competence (Adapted by Kowal and Roztocki from Bassellier and Benbasat (2004))

\begin{tabular}{|c|c|c|}
\hline Dimension & & Business Competence Regarding Organization Specific Knowledge - OSK \\
\hline $\begin{array}{l}\text { Organizational } \\
\text { Overview }\end{array}$ & OVR1 & $\begin{array}{l}\text { Rate your level of knowledge of the organization's external environment (e.g. government, competitors, suppliers, } \\
\text { and customers) }\end{array}$ \\
\hline \multirow[t]{3}{*}{ (OVR) } & OVR2 & Rate your level of knowledge of the goals and objectives of the organization as whole \\
\hline & $\mathrm{OVR}_{3}$ & Rate your level of knowledge of the core capabilities of the organization \\
\hline & OVR4 & Rate your level of knowledge of the key factors that must go right for the organization to succeed \\
\hline $\begin{array}{l}\text { Organizational } \\
\text { Units }\end{array}$ & UNT1 & $\begin{array}{l}\text { Rate your level of knowledge of the main challenges that different divisions in the organization face in achieving their } \\
\text { objectives. }\end{array}$ \\
\hline \multirow[t]{3}{*}{ (UNT) } & UNT2 & $\begin{array}{l}\text { Rate your level of knowledge of the language (e.g. key concepts, jargon, ect.) of the different divisions in the } \\
\text { organization }\end{array}$ \\
\hline & $\mathrm{UNT}_{3}$ & How well do you understand the work processes of the different divisions in your organization? \\
\hline & $\mathrm{UNT}_{4}$ & $\begin{array}{l}\text { Rate your level of knowledge of the connections and interdependencies between the various divisions in the } \\
\text { organization }\end{array}$ \\
\hline $\begin{array}{l}\text { Organizational } \\
\text { Responsibility }\end{array}$ & RES1 & To what extend do you take actions to stay informed about business development not directly related to IT? \\
\hline \multirow[t]{3}{*}{ (RES) } & RES2 & How much do you participate in business activities that are not directly related to IT? \\
\hline & $\mathrm{RES}_{3}$ & To what extent are you concerned by the overall performance of your business organization? \\
\hline & RES4 & To what extent does your work have an impact on the performance of the organization? \\
\hline $\begin{array}{l}\text { IT-Business } \\
\text { Integration }\end{array}$ & ITG1 & How experienced are you at recognizing potential ways to exploit new business opportunities using IT? \\
\hline \multirow[t]{5}{*}{ (ITG) } & ITG2 & $\begin{array}{l}\text { How experienced are you at analyzing business problems in order to identify IT-based solutions (understanding } \\
\text { situations, getting the "big picture" identifying underlying root problems, etc.)? }\end{array}$ \\
\hline & $\mathrm{ITG}_{3}$ & How experienced are you at evaluating the organizational impacts of IT solutions? \\
\hline & $\mathrm{ITG}_{4}$ & $\begin{array}{l}\text { Rate your level of knowledge of the alignment between business goals and information systems in the organization } \\
\text { as a whole }\end{array}$ \\
\hline & ITG5 & Rate your level of knowledge of the way IT contributes to the value of the organization \\
\hline & & Business Competence Regarding Interpersonal and Management Knowledge - IMK \\
\hline $\begin{array}{l}\text { Knowledge } \\
\text { Networking }\end{array}$ & NET1 & $\begin{array}{l}\text { If you have a business question or problem that you cannot solve alone, how confident are you about finding the } \\
\text { right person to contact in your organization? }\end{array}$ \\
\hline \multirow[t]{2}{*}{ (NET) } & NET2 & $\begin{array}{l}\text { If you have a business question or problem that you cannot solve alone, how confident are you about finding the } \\
\text { right contacts outside your organization (consultants, vendors)? }\end{array}$ \\
\hline & $\mathrm{NET}_{3}$ & $\begin{array}{l}\text { If you have a business question or problem that you cannot solve alone, how confident are you about finding other } \\
\text { relevant sources of business Information including Internet site, magazines, trade journals, and conferences? }\end{array}$ \\
\hline $\begin{array}{l}\text { Interpersonal } \\
\text { Communication }\end{array}$ & COM1 & $\begin{array}{l}\text { In general, how effective do you think you are at communicating with people at different levels of the organization } \\
\text { (e.g, with your subordinates, peers, superiors)? }\end{array}$ \\
\hline \multirow[t]{2}{*}{$(\mathrm{COM})$} & $\mathrm{COM}_{2}$ & How effective are you at working in a team environment? \\
\hline & $\mathrm{COM}_{3}$ & $\begin{array}{l}\text { How well can you communicate about IT matters in non-technical language and within a business context to non-IT } \\
\text { specialists? }\end{array}$ \\
\hline Leadership & LEA1 & In general, how effective do you think you are at managing projects (planning, managing resources, evaluating, etc.)? \\
\hline \multirow[t]{3}{*}{ (LEA) } & LEA2 & $\begin{array}{l}\text { In general, how effective do you think you are at acting in a leadership role (e.g. establishing direction, directing } \\
\text { people, motivating and inspiring, etc.) }\end{array}$ \\
\hline & LEA3 & Rate your level of knowledge of the existing practices for the management of change in the organization. \\
\hline & LEA4 & Rate your level of knowledge of the risk management practices that can be applied in the organization. \\
\hline $\begin{array}{l}\text { Partnerships } \\
\text { Intension }\end{array}$ & INT1 & $\begin{array}{l}\text { To what extent are you willing / ready to share responsibility with the company's customers for the development and } \\
\text { implementation of future projects? }\end{array}$ \\
\hline \multirow[t]{2}{*}{ (INT) } & INT2 & $\begin{array}{l}\text { How much would you be comfortable / you'd be willing / and create their business customers to implement projects } \\
\text { that may require more innovative technologies related to the risk? }\end{array}$ \\
\hline & $\mathrm{INT}_{3}$ & $\begin{array}{l}\text { To what extent would you be / you'd be willing / and in the future to develop a strong partnership with business } \\
\text { customers? }\end{array}$ \\
\hline \multicolumn{3}{|r|}{ All items are measured on a 5-point Likert-type scale: very low (1), low (2), neutral (3), high (4), very high (5) } \\
\hline
\end{tabular}

The coefficients of validity and reliability of the data fit were very satisfactory and depicted in Table 56. questionnaire and coefficients of the empirical model 


\subsection{Data Collection and Descriptive Analysis}

The on-line survey was conducted by the author through the website of the LABSEE in Olsztyn, Poland. From October 2015 to May 2016, 169 knowledge workers of regional small enterprises of region of Lower Silesia completed the survey. The trials construction included the methods of random interpersonal network and sequence sampling [21, 49] with the passive optimal experiment design $[20,50,53$, 54]. Contact information of potential respondents was retrieved from two databases: one compiled by the Centre for Scientific Research of College of Management "Edukacja" and the data of the statistical office of Lower Silesia. These databases comprise several thousand representative addresses of knowledge workers from across the region. The representativeness of the knowledge workers trial was controlled by such variables, as the respondents' age, gender, income level, and the size of the company.

A trial characteristic is described in Table 3.

Table 3. Sample Characteristics - Means and Frequencies

\begin{tabular}{|c|c|c|c|c|c|c|c|c|}
\hline \multirow[t]{2}{*}{\begin{tabular}{|l|} 
Variables \\
\end{tabular}} & \multicolumn{2}{|c|}{ Firm size } & \multicolumn{2}{|c|}{ Gender } & \multicolumn{2}{|c|}{ Micro firms } & \multicolumn{2}{|c|}{ Small firms } \\
\hline & Micro & Small & Female & Male & Female & Male & Female & Male \\
\hline \multicolumn{9}{|l|}{ Professional groups } \\
\hline Owner & $.40^{*}$ & $.16^{*}$ & $.23^{*}$ & $.32^{*}$ & .14 & .17 & $.30^{*}$ & $.54^{*}$ \\
\hline $\begin{array}{l}\text { Director or member of the management } \\
\text { board }\end{array}$ & .15 & .10 & .10 & .15 & .09 & .12 & .11 & .20 \\
\hline Manager & $.09^{*}$ & $.20^{*}$ & .13 & .15 & .20 & .19 & .09 & .09 \\
\hline Specialists - knowledge workers & .46 & .48 & $.43^{*}$ & $.52^{*}$ & $.43^{*}$ & $.52^{*}$ & $.43^{*}$ & $.51^{*}$ \\
\hline $\begin{array}{l}\text { Officials and personal services workers, } \\
\text { vendors, technicians }\end{array}$ & $.55^{*}$ & $.47^{*}$ & $.56^{*}$ & $.46^{*}$ & $.51^{*}$ & $.44^{*}$ & $.60^{*}$ & $.49^{*}$ \\
\hline \multicolumn{9}{|l|}{ Economic sectors } \\
\hline $\begin{array}{l}\text { Service activities other than those listed } \\
\text { below }\end{array}$ & .30 & .25 & $.20^{*}$ & $.36^{*}$ & $.09^{*}$ & $.37^{*}$ & .28 & .34 \\
\hline Information and communication & .11 & .07 & .07 & .10 & .06 & .08 & .09 & .14 \\
\hline Health care and social assistance & .10 & .10 & .12 & .08 & .11 & .10 & .13 & .06 \\
\hline $\begin{array}{l}\text { Wholesale and retail trade; repair of motor } \\
\text { vehicles, etc. }\end{array}$ & .10 & .07 & .07 & .09 & .06 & .08 & .09 & .11 \\
\hline $\begin{array}{l}\text { Professional, scientific and technical } \\
\text { activity }\end{array}$ & .09 & .08 & .09 & .08 & .14 & .04 & .04 & .14 \\
\hline Education & .07 & .08 & .11 & .05 & .14 & .04 & .09 & .06 \\
\hline Agriculture, forestry, hunting and fishing & .07 & .00 & .05 & .02 & .00 & .00 & .09 & .06 \\
\hline Business administration services & .06 & .11 & $.04^{*}$ & $.14^{*}$ & $.03^{*}$ & $.17^{*}$ & .04 & .09 \\
\hline Construction & .05 & .08 & .02 & .10 & .03 & .12 & .02 & .09 \\
\hline $\begin{array}{l}\text { Activities with accommodation and food } \\
\text { service }\end{array}$ & .05 & .02 & .06 & .01 & .03 & .02 & .09 & .00 \\
\hline Mining and quarrying & .05 & .01 & .02 & .03 & .00 & .02 & .04 & .06 \\
\hline $\begin{array}{l}\text { Cultural activities, entertainment and } \\
\text { recreation }\end{array}$ & .04 & .03 & .06 & .01 & .06 & .02 & .06 & .00 \\
\hline Water supply, and waste cloths etc. & .02 & .01 & .01 & .02 & .03 & .00 & .00 & .06 \\
\hline Transportation and storage & .02 & .05 & .02 & .05 & .06 & .04 & .00 & .06 \\
\hline Age (means) & 30.82 & 33.37 & $28.00^{*}$ & $36.02^{*}$ & $28.51^{*}$ & $36.63^{*}$ & $27.62^{*}$ & $35.11^{*}$ \\
\hline Salary level ranks (1-5) & 3.07 & $3 \cdot 3^{8}$ & $2.83^{*}$ & $3.61^{*}$ & $2.97^{*}$ & $3.65^{*}$ & $2.72^{*}$ & $3.54^{*}$ \\
\hline $\begin{array}{l}\text { Time spent by computer at work in ranks } \\
(1 \text { to } 3)\end{array}$ & $2.15^{*}$ & $2.55^{*}$ & $2.05^{*}$ & $2.64^{*}$ & $2.26^{*}$ & $2.75^{*}$ & $1.89^{*}$ & $2.49^{*}$ \\
\hline Gender & & & $.57^{*}$ & $.43^{*}$ & $.57^{*}$ & $.43^{*}$ & $.40^{*}$ & $.60^{*}$ \\
\hline \multicolumn{9}{|l|}{ Education } \\
\hline Secondary & .33 & .31 & .32 & .32 & .29 & .33 & .34 & .31 \\
\hline Bachelor or engineer degree & $.38^{*}$ & $.47^{*}$ & $.37^{*}$ & $.48^{*}$ & $.37^{*}$ & $.54^{*}$ & .36 & .40 \\
\hline Master degree & .22 & .18 & $.26^{*}$ & $.15^{*}$ & $.29^{*}$ & $.12^{*}$ & .23 & .20 \\
\hline Postgraduate studies & .07 & .03 & .06 & .05 & .06 & .02 & .06 & .09 \\
\hline
\end{tabular}

The results of proportions test and U Mann's Test for ranks. $N=169$ : Differences at the significance level of less than 0.05 ( $\mathrm{p}<0.05)$ are marked with stars *. 
Table 4. Statistical Summary - Results of Means Comparisons of Business Competence Self-assessment in Relation to Gender and Firm Size (Student's T Test)

\begin{tabular}{|c|c|c|c|c|c|c|c|c|}
\hline Means & \multicolumn{2}{|c|}{ Gender } & \multicolumn{2}{|c|}{ Firm size } & \multicolumn{2}{|c|}{ Micro firms } & \multicolumn{2}{|c|}{ Small firms } \\
\hline $\begin{array}{l}\text { Business } \\
\text { Category }\end{array}$ & $\begin{array}{c}\text { Females } \\
(\mathrm{N}=82)\end{array}$ & $\begin{array}{c}\text { Males } \\
(\mathrm{N}=87)\end{array}$ & $\begin{array}{c}\text { Micro } \\
(\mathrm{N}=82)\end{array}$ & $\begin{array}{c}\text { Small } \\
(\mathrm{N}=87)\end{array}$ & $\begin{array}{c}\text { Females } \\
(\mathrm{N}=47)\end{array}$ & $\begin{array}{c}\text { Males } \\
(\mathrm{N}=35)\end{array}$ & $\begin{array}{c}\text { Females } \\
(\mathrm{N}=35)\end{array}$ & $\begin{array}{c}\text { Males } \\
(\mathrm{N}=52)\end{array}$ \\
\hline OSK & $3.56^{*}$ & $4.09^{*}$ & 3.73 & 3.93 & $3.60^{*}$ & $3.89^{*}$ & $3.51^{*}$ & $4.22^{*}$ \\
\hline OVR & $3.78^{*}$ & $4.22^{*}$ & 3.93 & 4.09 & $3.79^{*}$ & $4.11^{*}$ & $3.77^{*}$ & $4.30^{*}$ \\
\hline UNT & $3.87^{*}$ & $4.1^{*} 5$ & 3.93 & 4.09 & 3.91 & 3.96 & $3.81^{*}$ & $4.28^{*}$ \\
\hline RES & $3.50^{*}$ & $4.04^{*}$ & 3.68 & 3.87 & 3.59 & 3.81 & $3.38^{*}$ & $4.20^{*}$ \\
\hline ITG & $3.10^{*}$ & $3.94^{*}$ & $3.37^{*}$ & $3.68^{*}$ & $3.13^{*}$ & $3.70^{*}$ & $3.06^{*}$ & $4.10^{*}$ \\
\hline IMK & $3.53^{*}$ & $3.93^{*}$ & $3.59^{*}$ & $3.87^{*}$ & 3.56 & 3.62 & $3.49^{*}$ & $4.13^{*}$ \\
\hline NET & 3.79 & 4.23 & $3.87^{*}$ & $4.16^{*}$ & 3.82 & 3.92 & $3.75^{*}$ & $4.44^{*}$ \\
\hline COM & 3.92 & 4.25 & $3.94^{*}$ & $4.23^{*}$ & 3.93 & 3.96 & $3.91^{*}$ & $4.44^{*}$ \\
\hline LEA & $3.71^{*}$ & $4.09^{*}$ & $3.74^{*}$ & $4.06^{*}$ & 3.78 & 3.69 & $3.61^{*}$ & $4.36^{*}$ \\
\hline INT & $3.81^{*}$ & $4.39^{*}$ & $3.94^{*}$ & $4.26^{*}$ & 3.82 & 4.10 & $3.79^{*}$ & $4.58^{*}$ \\
\hline BC $=$ OSK + IMK & $3.55^{*}$ & $4.01^{*}$ & $3.66^{*}$ & $3.90^{*}$ & $3.5^{8}$ & 3.77 & $3.50^{*}$ & $4.18^{*}$ \\
\hline
\end{tabular}

The results of Student's T Test for two means. N=169: Differences at the significance level of less than 0.05 (p $<0.05$ ) are marked with stars *.

Table 5. Factor Loadings $(\lambda)$ and Pearson's Correlation Coefficients (r), $\mathrm{N}=169, \mathrm{p}<0.05$

\begin{tabular}{|l|c|c|}
\hline Relation & $\lambda$ & $r$ \\
\hline Gender-9->(BC) & 0.5 & -0.4 \\
\hline Firm Size-10->(BC) & 0.51 & 0.2 \\
\hline (BC)-1->(OSK) & 0.78 & 1 \\
\hline (BC)-1->(IMK) & 1 & 0.9 \\
\hline (OSK)-1-> [OVR] & 0.85 & 0.8 \\
\hline (OSK)-2->[UNT] & 0.93 & 0.9 \\
\hline (OSK)-3-> [RES] & 0.89 & 0.9 \\
\hline (OSK)-4->[ITG] & 0.78 & 0.9 \\
\hline (IMK)-5-> [NET] & 0.79 & 0.9 \\
\hline (IMK)-6-> [COM] & 0.87 & 0.9 \\
\hline (IMK)-7->[LEA] & 0.88 & 0.9 \\
\hline (IMK)-8->[INT] & 0.67 & 0.8 \\
\hline
\end{tabular}

Table 6. Model fit in SEM, where AVE - average variance extracted, $\alpha-$ Cronbach's $\alpha, r$ - mean correlation between items, $\mathrm{p}$ - observed probability, $x^{2} / \mathrm{df}$, RMSEA, GFI, AGFI - indicators of model fit

\begin{tabular}{|c|c|c|c|c|c|c|c|c|}
\hline Construct & AVE & $\alpha$ & $\mathrm{r}$ & $x^{2} / d f$ & RMSEA & $p$ & GFI & AGFI \\
\hline Model & 0.7 & 0.8 & 0.1 & 2.82 & $<.072$ & 0.06 & 0.99 & 0.92 \\
\hline OVR & 0.7 & 0.99 & 0.9 & 1.7 & $<.06$ & 0.17 & 0.99 & 0.92 \\
\hline UNT & 0.7 & 0.99 & 0.9 & 0.21 & $<.0001$ & 0.82 & 0.999 & 0.99 \\
\hline RES & 0.6 & 0.93 & 0.4 & 12 & $<.15$ & 0.0001 & 0.91 & 0.5 \\
\hline ITG & 0.77 & 0.95 & 0.6 & 6.29 & $<.16$ & 0.0001 & 0.94 & 0.82 \\
\hline NET & 0.77 & 0.93 & 0.7 & 0.01 & $<.01$ & 0.99 & 0.99 & 0.99 \\
\hline COM & 0.79 & 0.92 & 0.6 & 0.01 & $<.01$ & 0.99 & 0.99 & 0.99 \\
\hline LEA & 0.74 & 0.87 & 0.4 & 11 & $<.14$ & $<.001$ & 0.93 & 0.7 \\
\hline INT & 0.62 & 0.75 & 0.41 & 0.01 & $<.01$ & 0.99 & 0.99 & 0.99 \\
\hline OSK & 0.7 & 0.94 & 0.45 & 2.21 & $<.09$ & $<.01$ & 0.82 & 0.8 \\
\hline IMK & 0.7 & 0.92 & 0.48 & 2.97 & $<.10$ & $<.01$ & 0.82 & 0.8 \\
\hline BC & 0.7 & 0.96 & 0.45 & 3.86 & $<.07$ & $<.01$ & 0.7 & 0.7 \\
\hline
\end{tabular}

The sample of knowledge workers consisted of 82 female and 87 male respondents. Females in the study were noted to be younger than males. The average age for female respondents was 28 years as compared to 36 years for male respondents. As can be seen from Table 3 , males in regional small firms are more often owners, directors or managers, and specialists. Female employees are more likely to be involved in personnel services, or work as vendors, or technicians.

Female knowledge workers are more likely than male to work for micro companies (57 percent female to 43 percent male). Male knowledge workers more often were employed in small firms ( 40 percent female, 60 percent male). The percentages of employed knowledge workers were in contrast on a country level as previously reported by Kowal and Roztocki [31].

In Lower Silesia region, Poland, knowledge workers were noted to find employment in such sectors as business administration services, information and communication, construction, wholesale and retail trade. These retail trade industries include the repair of motor vehicles, health care and social assistance services, and professional, scientific or other technical functions.

Both sexes as knowledge workers find job in service activities, as business administration services, health care and social assistance, education, professional, scientific and technical activity, information and communication, wholesale and retail 
trade; repair of motor vehicles, etc., activities with accommodation and food service, cultural activities, entertainment and recreation, agriculture, forestry, hunting and fishing. Males are employed more frequently than females in service activities, business administration services and in construction.

While earned terminal degrees were comparable among genders, it can be observed that a larger portion of males than females have a Bachelor or an engineering degree. Females, however, dominate the Master degree (Table 3).

\section{Results}

To find potential gender differences among knowledge workers who took part in the experimental survey, statistical analysis was completed and described below (Table 4 and Table 5).

\subsection{The Effect of Gender on BC Self- assessment}

According to the results depicted in Table 4 female subjects evaluate themselves less qualified in global Business Competencies (BC) than their male counterparts (the mean for females $\mathrm{Mf}=3.55$, the mean for males $\mathrm{Mm}=4.01)$, and in dimension of OSK $(\mathrm{Mf}=$ 3.56, $\mathrm{Mm}=4.09)$, and its subscales OVR $(\mathrm{Mf}=3.78$, $\mathrm{Mm}=4.22)$, UNT $(\mathrm{Mf}=3.87, \mathrm{Mm}=4.1)$, RES $(\mathrm{Mf}=$ 3.50, Mm= 4.04), ITG $(\mathrm{Mf}=3.10 \mathrm{Mm}=3.94)$. Less number of differences was related to IMK. The dimension IMK was differentiated globally $(\mathrm{Mf}=3.53$, $\mathrm{Mm}=3.93)$, and in such subscales as LEA $(\mathrm{Mf}=3.71$, $\mathrm{Mm}=4.09)$ and INT $(\mathrm{Mf}=3.81, \mathrm{Mm}=4.39)$. There were no differences in subscales: NET $(\mathrm{Mf}=3.79$, $\mathrm{Mm}=4.23)$, and $\mathrm{COM}(\mathrm{Mf}=3.92, \mathrm{Mm}=4.25)$. The differences between females and males are significant for self-assessment of the global BC and its subscales: OSK and IMK. Thus, Hypothesis (H1) seems to be supported.

The effect of gender can be observed in relation to firm size. In small firms that employ from 10 to 49 employees, gender differences have a greater effect on self-assessment of business competencies than in micro firms employing up to 9 persons. This was demonstrated in small firms for dimensions of $\mathrm{BC}$, OSK, ITM and their subscales where females evaluated themselves less competent than males. Such tendencies related to OSK $(\mathrm{Mf}=3.51, \mathrm{Mm}=4.22)$, and its sub-dimensions: OVR $(\mathrm{Mf}=3.77, \mathrm{Mm}=4.30)$, UNT $(\mathrm{Mf}=3.81, \mathrm{Mm}=4.28), \operatorname{RES}(\mathrm{Mf}=3.38, \mathrm{Mm}=4.20)$, ITG $(\mathrm{Mf}=3.06 . \mathrm{Mm}=4.10)$. Also in the sphere of IMK males evaluate themselves more competent: IMK $(\mathrm{Mf}=$ 3.49, $\mathrm{Mm}=4.13)$, NET $(\mathrm{Mf}=3.75, \mathrm{Mm}=4.44), \mathrm{COM}$
$(\mathrm{Mf}=3.91, \mathrm{Mm}=4.44), \mathrm{LEA}(\mathrm{Mf}=3.61, \mathrm{Mm}=4.36)$, INT $(\mathrm{Mf}=3.79 . \mathrm{Mm}=4.58)$. Also, the male assessment of global BC was superior $(\mathrm{Mf}=3.50 \mathrm{Mm}=4.18)$. Females assess themselves best in the scales of COM, UNT, INT, OVR and NET, while males in the dimensions of INT, COM, NET, LEA, OVR, UNT. All males values were assessed as higher throughout the self-assessment In micro enterprises, the gender differences were not as evident. Thus, in micro firms the results concerning IMK are similar in both sexes in all sub-dimensions. The assessments are generally a little higher than middle point of the scale, but they rather are less than 4 . So means for both sexes were equal respectively to: $\mathrm{IMK}(\mathrm{Mf}=3.56, \mathrm{Mm}=3.62)$, NET $(\mathrm{Mf}=3.82, \mathrm{Mm}=3.92), \mathrm{COM}(\mathrm{Mf}=3.93, \mathrm{Mm}=$ 3.96), LEA $(\mathrm{Mf}=3.78, \mathrm{Mm}=3.69)$, INT $(\mathrm{Mf}=3.82$, $\mathrm{Mm}=4.10)$. The differences concerning $\mathrm{BC}$ scale were also nonsignificant $(\mathrm{Mf}=3.58, \mathrm{Mm}=3.77)$. Both sexes asses themselves the best in such dimensions as OVR, ITG, COM and UNT. In the dimensions of OSK were observed some significant differences and again females had worse results than males in such scales: OSK $(\mathrm{Mf}=3.60, \mathrm{Mm}=3.89)$, OVR $(\mathrm{Mf}=3.79, \mathrm{Mm}=$ 4.11), ITG $(\mathrm{Mf}=3.13, \mathrm{Mm}=3.70)$. There were no effect of gender in the spheres of UNT $(\mathrm{Mf}=3.91$, $\mathrm{Mm}=3.96)$, RES $(\mathrm{Mf}=3.59, \mathrm{Mm}=3.81)$. Hypothesis H1 seems to be supported here as well. However, the general conclusion is knowledge workers in micro firms evaluate themselves for $\mathrm{BC}$ worse than employees in small firms. and males self-assess higher than females across all scales.

\subsection{Organizational Size and Business Competencies Self-assessment}

Size of an organization or firm have differentiated employees in knowledge economy in their selfassessment of BC. Table 4 lists all dimensions of the construct. To answer the research questions and verify the hypotheses, Pearson's linear correlation coefficients determined the significance of the data. All correlations were significant, between gender, firm size and dimensions of $\mathrm{BC}$. The results are presented in Table 5-6. The proportion test $\mathrm{Z}$ and Student T-Test indicate that gender and firm size affect BC selfassessment. The canonical correlation coefficient related to gender, firm size and the business competencies dimensions is statistically significant ( $p$ $<0.05$ ) with a strength of corr $=0.5$, at the moderate level. 


\subsection{The Global Research Model}

In order to examine the hypotheses of the conceptual model depicted in Figure 1, a series of analysis using SEM are listed in Table 5 and $6[18,44$, 47]. Current proposed empirical SEM confirmed two parts: 1) the measurement model which related measured observable variables [OVR, .., INT] to latent variables (in ellipses: BC, OSK, IMK, Gender, Firm size); 2) the structural model that related latent variables to one another (Gender $\rightarrow(\mathrm{BC})$, Firm size $\rightarrow(B C), B C \rightarrow($ OSK, IMK $))$, with variables $d 1, d 2$, o1,...o3 as residuals. Tables 5-6 depict empirical correlations and the SEM analysis that confirmed the influence of gender and firm size on $\mathrm{BC}$ and its dimensions. Thus main hypotheses $\mathrm{H} 1-\mathrm{H} 2$ and their sub-hypotheses seem to be supported.

\section{Conclusions, Discussion, Contribution}

Overall, the gender of knowledge workers and firm size of a company in transition economies appear to have an effect on some dimensions of business competencies self-assessment, namely knowledge on organizational overview, organizational units, organizational responsibility, IT-business integration, knowledge networking, interpersonal communication, leadership and intention of partnership development. This conclusion is a little bit different than results of some studies in more developed countries [10, 14, 15, $22,41]$ or transition countries [2, 34].

The results of current study showed that gender plays a role in business competencies self-assessment in the knowledge workers profession in regional small enterprises in Poland, a transition economy. The comparison of the results to business competencies studies reported in developed countries [1] shows a more difficult professional position, resulting in less business competencies self-assessment for females working as knowledge workers in small regional enterprises in transition economies, such as Poland. The results of current research show that females who work as knowledge workers in regional small enterprises in Poland manifest (in their own assessment) less levels of business competencies than male colleagues. However female manifest the highest scores in sphere of knowledge concerning organizational units and organizational responsibility. The micro firms have worse economic position, less technological support what can cause less self-efficacy [3] and conviction about knowledge workers less BC.

Females constitute a majority of the unemployed workforce in Poland where these individuals have the same or even higher education than their male counterparts. Often female workers are impacted by the prevailing cultural stereotypes of this gender being responsible for the family and therefore, not focused on the workforce [14, 32, 33]. This stereotype makes a female knowledge worker less attractive to employ in the IT field and often seen as a "family fireside protector" $[32,33]$.

Current study presented in this paper has a substantial contribution to the existing resources of knowledge economics research for several reasons. First, it may be the first study that examines gender differences on the basis of business competencies selfassessment among knowledge workers in small regional enterprises, in transition economies. Second, the study shows that female knowledge workers in transition economies have a reduced sense of business competencies than their male counterparts. This is unique and different from most findings in developed, mature economies. The majority of these studies claim that gender does not play a role in business competencies among knowledge workers [10, 48]. The conclusions of current study may find practical application in more efficient use of management instruments of regional SME's managers, companies, local governments and politicians, to help females in their more difficult position. Finances from local governments could promote business competency for females within small businesses. Training assistance can provide information about the role of business competence and methods to improve competencies within transitional economies [20, 24, 25].

Creation of new projects for female knowledge workers may benefit them by allowing skills development and competencies with a focus on microenterprises [20,25]. Current conditions are insufficient to help female workers overcome the barriers $[15,32$ 33]. Improvement in the financial sector, free consulting services, lifelong learning opportunities and tax breaks, could develop economic transformation and can help females to set up and run successfully their own companies. European Union projects are currently seeking new ways of solving inequality and discrimination problems.

Future research avenues may investigate the reasons for job dissatisfaction among female knowledge workers in transition economies with qualitative interview methodology. A different study may examine how business competencies could be improved. This type of study may help to close the existing gap between developed and transition economies [42, 43, 45]. Development of the new strategies, including gender differences, should support innovation, by improving business competencies of knowledge workers in small regional enterprises. It can be also beneficial for other organizations. 


\section{Acknowledgments}

The author would like to thank Julee Hafner and Juho Mäkiö for valuable suggestions and professional proofreading, as also thank knowledge workers who agreed to take part in the research.

\section{References}

[1] M.K. Ahuja,'Female in the Information Technology Profession: A Literature Review, Synthesis and Research Agenda," European Journal of Information Systems, 11(1), pp. 20-34, 2002

[2] L. Auhadeeva,I. E. Yarmakeev, A. E. Aukhadeev,"Gender Competence of the Modern Teacher," International Education Studies, 8(2), pp. 32-37, 2015.

[3] [A. Bandura,"Self-efficacy: Towards a Unifying Theory of Behavioral Change," Psychological Review, 84(2), pp. 191-215, 1977.

[4] G. Bassellier, I. Benbasat,'Business competence of information technology professionals: conceptual development and influence on IT-business partnerships," MIS Quarterly 28(4): pp. 673-694, 2004.

[5] J. Belas, V. Demjan, J. Habánik, M. Hudáková, J. Sipko,"The business environment of small and medium-sized enterprises in selected regions of the Czech Republic and Slovakia," Economics and Management, 18(1), 2015, doi: dx.doi.org/10.15240/tul/001/2015-1-008.

[6] I. Brinkley,"Defining the knowledge economy," The Work Foundation, London, 2006.

[7] C. Brockmann, N. Roztocki,"Topics on Knowledge Management: An Empirical Insight into Articles Published in the International Journal of Knowledge Management," 48th Hawaii International Conference (HICSS), pp. 3834-3840, IEEE, 2015.

[8] C. Brockmann, Roztocki, N,"The Evolution of Knowledge Economics through the Course of Time: An Analysis of the Hawaii International Conference on System Sciences," (HICSS) 47th Hawaii International Conference, pp. 3471-3477, IEEE, 2014.

[9] A.E. Clark,"Business competencies and Gender: Why are female so Happy at Work?," Labour Economics, 4(4), pp. 341-372, 1997 .

[10] B. J. Crump, K. A. Logan, and A. McIlroy,'Does Gender Still Matter? A Study of the Views of Women in the ICT Industry in New Zealand," Gender, Work and Organization, 14 (4), July 2007

[11] P. F. Drucker,'The Landmarks of Tomorrow," Harper and Row, 1959.

[12] P.F. Drucker,"Post-Capitalist Society," New York: Harper Bus, 1993.

[13] F.Herzberg,"The New Industrial Psychology," Industrial and Labor Relations Review, 18(3), pp. 364-376, 1965
[14] F. Herzberg, B. Mausner, and B.B. Snyderman,'The Motivation to Work," 2nd ed. New York: John Wiley \& Sons, 1959.

[15] N. Harris, P. Cushman, S.E. Kruck, R.D. Anderson,"Technology Majors: Why Are female Absent?," Journal of Computer Information Systems, 50(2), pp. 23-30, 2009.

[16] J. Henderson, S. Weiler,'Entrepreneurs and job growth: probing the boundaries of time and space," 24(1), pp. 23-32, 2010,doi:10.1177/0891242409350917.

[17] R. Hisrich, M. Peters,"Enterpreneurship: starting, developing and managing a new enterprise," Boston: Homewood, pp. 65, 1992.

[18] J.J.Hox, T. M. Bechger,"An introduction to structural equation modelling," Family Science Review 11, pp. 354373, 1998.

[19] M. Igbaria, J. Baroudi,'The Impact of Job Performance Evaluations on Career Advancement Prospects: An Examination of Gender Differences in the IS Workplace," MIS Quarterly, 19(1), pp. 107-123, 1995.

[20] A. Jasińska-Biliczak, J. Kowal, J. Hafner,'Innovative Capacity in Small Regional Enterprises in Transition Economies: An Exploratory Study in Poland," $2^{\text {nd }}$ Americas Conference on Information Systems, San Diego, 2016.

[21] G. Kalton, M. Collins, L. Brook,"Experiments in Wording Opinion Questions,"Applied Statistics, 27, pp. 149161,1978

[22] L. Kakkonen,'Learning Entrepreneurial Competencies in an International Undergraduate Degree Programme. A Follow-Up Study," Dissertations in Education, Humanities, and Theology No 36, University of Eastern Finland, 2012.

[23] A. Keplinger, J. Kowal, J. Mäkiö,,"Gender and Organizational Citizenship Behavior of Information Technology Users in Poland and Germany,"22 ${ }^{\text {nd }}$ Americas Conference on Information Systems (AMCIS), San Diego, 2016,http://aisel.aisnet.org/amcis2016/ICTs/Presentations/10.

[24] J. Kowal, A. Gurba,"Mobbing and Burnout in Emerging Knowledge Economies: An Exploratory Study in Poland," 2016 49th Hawaii International Conference on System Sciences Conference (HICSS), IEEE, 2016.

[25] J. Kowal, A. Jasińska-Biliczak,"Socio-Demographic Factors of Innovative Capacity of IT Professionals in Small Regional Enterprises in Transition Economies," European, Mediterranean \& Middle Eastern Conference on Information Systems 2016 (EMCIS2016), June 23th - 24th 2016, Krakow, Poland.

[26] J. Kowal, A. Keplinger,"Characteristes of Human potentiality and Organizational behavior among IT users in Poland. An exploratory study,"Ekonometria. Econometrics, 3(49), 2015.98-114. http://econometrics.ue.wroc.pl/?lang=pl.

[27] J. Kowal, A. Keplinger, J. Mäkiö, R. Sonntag,” Does Human Potentiality Affect IT Professionals' Organizational Behavior? An Experimental Study in Poland and Germany," LNBIP, Business Information Systems, Springer, pp. 179194. 
[28] J. Kowal, A. Kwiatkowska, W. Kowal,'IT Project Management in Relation to Employees' Competence in Poland," ECMLG 2011 Proceedings, Reading, UK: Academic Publishing Limited, pp. 216-226, 2011.

[29] J. Kowal, J., Roztocki, N.,'Does Organizational Ethics Improve IT Job Satisfactoin In The VISEGRÁD Group Countries? Insights From Poland," Journal of Global Information Technology Management, 2015, doi= 10.1080/1097198X.2015.1052687.

[30] J. Kowal, N. Roztocki,'Information and Communication Technology Management for Global Competitiveness and Economic Growth in Emerging Economies," The Electronic Journal of Information Systems in Developing Countries, 57, 2013.

[31] J. Kowal, N. Roztocki,"Job satisfaction of IT professionals in Poland: does business competence matter?," Journal of Business Economics and Management, 16(5), pp. 995-1012, 2015, doi: 10.3846/16111699.2014.924988.

[32] J. Kowal, N. Roztocki,"Gender and job satisfaction of information technology professionals in Poland," Proceedings of the Annual Hawaii International Conference on System Sciences (HICSS), pp. 3625-3634, http://dx.doi.org/10.1109/HICSS.2016.453.

[33] J. Kowal, K. Weglowska-Rzepa,"Women's Situation and Management Competencies on the Example of Poland: A Review and Research Survey," in She is in XXI Century, Poznań: MAIUSCULA, 2011, pp. 365-388.

[34] S. J. Linz,'Business competencies among Russian Workers," International Journal of Manpower, 24(6), pp. 625-652, 2003

[35] F. Machlup,"The Production and Distribution of Knowledge in the United States," Princeton, NJ: Princeton Univ. Press, 1962.

[36] Peneva, I., Yordzhev, K., \& Ali, A. S.: The Adaptation of Translation Psychological Test as a Necessary Condition for Ensuring the Reliability of Scientific Research. IJESIT, 2(4), pp. 557-560, 2013.

[37] W. W. Powell and K. Snellman,"The Knowledge Economy," Annu. Rev. Sociol. 30, pp.199-220, 2004.

[38] N. Roztocki, H.R. Weistroffer,"Research Trends in Information and Communications Technology in Developing, Emerging and Transition economies," Annals of the Collegium of Economic Analysis, 20, pp.113-127, 2009.

[39] N. Roztocki and H.R. Weistroffer,'Information Technology in Transition Economies," Journal of Global Information Technology Management, 11(4), pp. 2-9, 2008.

[40] N. Roztocki and H.R. Weistroffer,'Information and Communication Technology in Transition Economies: An Assessment of Research Trends," Information Technology for Development, 21(3), pp. 330-364, 2015.

[41] S. Ryan and G. Harden,"Job Embeddedness of Information Technology Professionals: The Effects of
Gender," The Journal of Computer Information Systems, 54(4), pp. 52-59, 2014.

[42] N. Roztocki, H.R. Weistroffer,"From the Special Issue Editors: Information Technology in Transition Economies," Information Systems Management, 28(3), pp. 188-191, 2011.

[43] N. Roztocki, H. R. Weistroffer,'Information and Communication Technology in Transition Economies: An Assessment of Research Trends," Information Technology for Development, 21(3), pp. 330-364, 2015.

[44] A. Sagan, "Zastosowanie wielowymiarowych skal czynnikowych i skal Rascha w badaniach marketingowych (na przykładzie oceny efektów komunikacyjnych reklamy)," Zeszyty Naukowe nr 605, AE Kraków, pp. 73-92, 2002.

[45] P. Soja and P. R. da Cunha,"ICT in Transition Economies: Narrowing the Research Gap to Developed Countries," Information Technology for Development, 21(3), 2015.

[46] P.E. Spector,"Measurement of Human Service Staff Satisfaction: Development of the Business competencies Survey," American Journal of Community Psychology, 13(6), pp. 693-713, 1985.

[47] M. Straś-Romanowska, J. Kowal, M. Kapała,’How to Measure Spiritual Sensivity at The It User's Workplace? The Construction Process and Method of Validation of Spiritual Sensitivity Inventory (SSI)," Econometrics, 2(52), 2016.

[48] M. Sumner, F. Niederman,'The Impact of Gender Differences on Job Satisfaction, Job Turnover, and Career Experience of Information Systems Professionals ", The Journal of Computer Information Systems, 44(2), pp. 29-39, 2003.

[49] S. Sudman, E. Blair ,"Sampling in the Twenty-First Century," Journal of the Academy of Marketing Science, 27(2), pp. 269-277, 1999.

[50] G. Taguchi, Y. Wu, Introduction to Off-line Quality Control, Tokyo, Central Japan Quality Control Association, 1979.

[51] D. Tapscott, D. Ticoll and A. Lowy, "Digital Capital: Harnessing the Power of Business Webs, "Boston, Harvard Business School Press, 2000.

[52] R. Wild,'Job Needs, Job Satisfaction, and Job Behavior of female Manual Workers," Journal of Applied Psychology, 54(2), pp. 157-162, 1970.

[53] J.Wawrzynek, Statystyczne planowanie eksperymentów w zagadnieniach regresji w warunkach małej próby. Wrocław, Wyd. AE we Wrocławiu, 1993.

[54] C.F.Wu,"Some algorithmic aspects of the theory of optimal designs", Ann. Statist. vol. 6, pp. 1286-1301, 1978.

[55] M. Zou,"Gender, Work Orientation and Job Satisfaction," Work, Employment and Society, 29(1), pp. 322,2015 